\title{
HIKAYAT KALILAH DAN DAMINA: SEBUAH CERMINAN MODEL PENGAJARAN MORAL MELALUI CERITA HIKMAH
}

\section{HIKAYAT KALILAH AND DAMINA: A REFLECTION OF THE MORAL TEACHING MODEL THROUGH THE WISDOM STORY}

\author{
Dwi Apri Kurniawan, Asep Yudha Wirajaya \\ Program Studi Sastra Indonesia \\ Fakultas Ilmu Budaya, Universitas Sebelas Maret \\ dwiaprik11@gmail.com; asepyudha.w@gmail.com
}

\begin{abstract}
ABSTRAK
Permasalahan moral menjadi salah satu tantangan yang harus dihadapi oleh masyarakat pada zaman ini. Seiring berkembangnya arus globalisasi, nilai-nilai luhur budaya dan norma kian luntur dalam generasi muda sekarang. Pengajaran moral dipandang perlu ditanamkan melalui berbagai cara, salah satunya melalui karya sastra. Hikayat Kalilah dan Damina merupakan salah satu karya sastra klasik Melayu populer yang termasuk sebagai naskah kuno. Nilai-nilai hikmah dalam hikayat ini memiliki pesan moral tersendiri untuk para pembacanya. Sebagai cerminan ajaran moral, naskah Hikayat Kalilah dan Damina adalah bagian dari karya sastra masa lampau yang dapat dijadikan salah satu sumber pembelajaran moral manusia melalui cerita hikmah. Inti ajaran moral yang ingin disampaikan dan dicapai dari Hikayat Kalilah dan Damina adalah gambaran tentang manusia ideal, yakni manusia yang paham dan bertindak dalam nilai-nilai moral, yaitu manusia berakhlak. Cerita-cerita dalam Hikayat Kalilah dan Damina ini juga merupakan sebuah alternatif media pengajaran moral yang cocok diterapkan untuk anak-anak, karena cerita yang sebagian besar berkisah mengenai tokoh-tokoh binatang atau fabel adalah salah satu jenis cerita yang sangat digemari oleh anak-anak.
\end{abstract}

Kata kunci : hikayat, kalilah dan damina, manuskrip, moral, hikmah

\begin{abstract}
Moral problems become one of the challenges that must be faced by society today. As the currents of globalization develop, the noble values of culture and norms are fading in the younger generation now. Moral teaching is considered necessary to be instilled in various ways, one of which is through literary works. Hikayat Kalilah and Damina are one of the popular Malay classical literary works that are included as ancient manuscripts. The values of wisdom in this saga have their own moral message for their readers. As a reflection of moral teaching, the script of Hikayat Kalilah and Damina is part of past literary works that can be used as a source of human moral learning through wisdom stories. Moral is closely related to the limits that assess a human behavior in his life in society. Moral is also used as a benchmark to assess a person's actions in society, good or bad value. The stories in Hikayat Kalilah and Damina are an alternative moral teaching media that is suitable for children. Because the story which mostly
\end{abstract}


Tuah Talino

Tahun XIV Volume 14 Nomor 2 Edisi 4 Desember 2020

ISSN 0216-079X E-ISSN 2685-3043

Balai Bahasa Kalimantan Barat

revolves around animal figures or fables is one type of story that is very popular with children.

Keywords: hikayat, kalilah and damina, manuscript, morals, wisdom

\section{PENDAHULUAN}

Berkembangnya ilmu pengetahuan dan teknologi pada saat ini mengakibatkan mudahnya informasi dan pengaruh budaya asing yang tidak sesuai masuk ke dalam kehidupan kita. Salah satu dampak terbesar dari perubahan budaya yang cepat ini ialah lunturnya nilai-nilai luhur budaya tradisional dalam individu masyarakat diikuti dengan memudarnya kesadaran terhadap normanorma dan nilai moral yang telah ada sebelumnya. Hal ini terutama tampak pada generasi muda yang mulai lupa terhadap jati diri norma sosial dan tanggung jawab moral. Dalam Kamus Besar Bahasa Indonesia (2008: 971), moral diartikan sebagai suatu ajaran tentang baik buruk yang diterima umum mengenai perbuatan, sikap, kewajiban, dan sebagainya (akhlak; budi pekerti; susila). Permasalahan moral ini terjadi salah satunya karena kurangnya penanaman nilai-nilai moral pada individu-individu sejak dini. Salah satu bentuk pengajaran moral dapat dilakukan melalui karya sastra. Salah satu jenis karya sastra yang masyhur sejak lama dan banyak bermuatan pesan yang kuat terhadap para pembacanya adalah hikayat.

Hikayat secara bahasa berasal dari bahasa Arab "hikayah" yang mengandung arti "cerita". Hikayat merupakan salah satu jenis prosa Melayu Klasik. Hikayat adalah karangan yang isi peristiwanya tidak selalu benar-benar terjadi (Baried, 1979; Wirajaya (2019)Cerita dalam hikayat, misalnya berisi tentang sebuah riwayat hidup, cerita-cerita kuno, cerita sejarah, silsilah para penguasa atau raja, serta cerita kepahlawanan, yang di dalam ceritanya terkadang ditambahkan alur fiksi, tidak sesuai catatan sejarah, serta hal-hal yang tidak masuk akal. Hikayat selain berfungsi sebagai legitimasi sebuah kekuasaan, juga tidak jarang berfungsi sebagai bahan perenungan kehidupan manusia, salah satunya sebagai penyampaian pesan moral. Hikayat jenis ini biasanya berisi banyak cerita hikmah di dalamnya. Salah satu hikayat yang termasuk jenis tersebut adalah Hikayat Kalilah dan Damina.

Hikayat Kalilah dan Damina berisi banyak kumpulan cerita-cerita hikmah yang sering digunakan sebagai media pengajaran moral manusia. Hikayat Kalilah dan Damina adalah salah satu karya sastra masa lampau populer, baik yang telah ditulis maupun disalin dalam berbagai versi dan ke berbagai ragam bahasa. Awal mulanya, hikayat ini ditulis oleh seorang alim dari Hindustan yang bernama Baidaba dalam bahasa Sanskerta pada masa pemerintahan Maharaja Dabsyalim. Kemudian, hikayat ini disalin dalam Bahasa Parsi, Bahasa Tibet, Bahasa Suryani, dan Bahasa Arab. Dalam perkembangannya, Hikayat Kalilah dan Damina yang paling masyhur dan banyak dijadikan rujukan penyalinan pada masa-masa berikutnya adalah salinan berbahasa Arab yang ditulis oleh Abdullah Ibnul Muqaffa. Djamil dalam (Baidaba, 2002: 12-13) mengemukakan bahwa setidaknya salinan Abdul Ibnul Muqaffa ini diterjemahkan lagi oleh orang-orang ke dalam sepuluh bahasa dan menghasilkan sedikitnya dua puluh buah salinan. Adapun 
Tuah Talino

Tahun XIV Volume 14 Nomor 2 Edisi 4 Desember 2020

ISSN 0216-079X E-ISSN 2685-3043

Balai Bahasa Kalimantan Barat

salinan naskah dalam bahasa Melayu dan bahasa Indonesia berasal dari ceritacerita Pancatantra yang datang bersamaan dengan kesusasteraan Hindu yang lain. Winstead dalam (Braginsky, 1998). Wirajaya (2019) mengemukakan, cerita-cerita ini kemudian disalin atau disadur, disesuaikan dengan taraf alam pikiran mereka sehingga bertambah kayalah sastra Melayu dengan bahan-bahan cerita selama beberapa abad.

Berangkat dari penjelasan yang telah disebutkan sebelumnya bahwa mahsyurnya penyalinan naskah Hikayat Kalilah dan Damina pada masa itu merupakan bukti betapa hikayat ini memiliki kedudukan nilai yang berkesan di masyarakat, nilai-nilai yang diterima dari pembacaan hikayat ini hidup sebagai semangat spiritual masyarakat. Oleh karena itu, peneliti berasumsi bahwa Hikayat Kalilah dan Damina dapat dijadikan sebagai sebuah alternatif model pembelajaran moral bagi dunia pendidikan. Selain nilai-nilai tersebut dirasa masih relevan dengan situasi dan kondisi saat ini, juga pendidikan pada zaman milenial lebih diorientasikan pada pembentukan karakter.

Penelitian ini bertujuan untuk mengemukakan beberapa pesan moral yang terdapat di dalam teks Hikayat Kalilah dan Damina sebagai alternatif model pembelajaran moral bagi generasi yang akan datang. Dalam hal ini, dapat dikatakan bahwa bentuk-bentuk pembelajaran moral dapat dilakukan melalui penceritaan kisah hikmah adalah hal yang umum dipakai dalam masyarakat masa lampau. Isi dari setiap episode cerita teks ini banyak dipengaruhi oleh latar nilainilai sosial budaya (etika, tradisi, kekuasaan, agama, dan sebagainya). Berdasarkan dari pandangan tersebut, penulis mencoba untuk melakukan identifikasi dan deskripsi kandungan pesan moral Hikayat Kalilah dan Damina sebagai cerminan ajaran moral dalam hikayat tersebut dan memberikan kaitannya dengan model pembelajaran moral yang berlaku saat ini.

Penelitian ini memiliki manfaat untuk memberikan cerminan ajaran moral, yakni naskah Hikayat Kalilah dan Damina sebagai warisan karya sastra masa lampau yang dapat dijadikan obek peran moral melalui penyampaian cerita-cerita hikmah. Sebagai sebuah karya sastra, Hikayat Kalilah dan Damina memiliki nilai pengajaran moral dan karakter tersendiri. Sebab, sebuah karya sastra pada hakikatnya berisikan cerminan kehidupan manusia, serta persoalan kehidupan yang disampaikan dengan bahasa yang khas. Wirajaya (2007) memandang, kisahkisah yang mengandung hikmah dalam hikayat ini adalah salah satu bentuk pengajaran moral.

Moral erat kaitannya dengan kaidah norma dan sistem tingkah laku seseorang dalam suatu kelompok sosial dan masyarakat (Chilmiy, 2014: 7). Moral dijadikan pula sebagai dasar untuk menilai suatu tindakan seseorang dalam masyarakat, bernilai baik atau buruk. Dalam dunia pendidikan, kekuatan moral berkaitan dengan budi pekerti seseorang dalam pengembangan watak. Hal itu kemudian dijadikan sebagai acuan dalam menghayati nilai kejujuran, disiplin, dan kerja sama. Moralitas dan pendidikan moral dapat ditinjau dari dua sisi, yakni dari sisi luar yang memandang moralitas untuk mengantur cara berperilakudengan orang lain dan sisi dalam yang memandang moralitas sebagai cara menata dalam diri sendiri. Dengan kata lain, pendidikan moral perlu dilakukan untuk kontrol kondisi sosial dan aktualisasi diri sendiri (Hasanah, 2019:133). 
Tuah Talino

Tahun XIV Volume 14 Nomor 2 Edisi 4 Desember 2020

ISSN 0216-079X E-ISSN 2685-3043

Balai Bahasa Kalimantan Barat

Fokus masalah nilai-nilai moral atau budi pekerti menurut Rianto (dalam Zuriah, 2007: 27) dibagi menjadi tiga kelompok, yakni masalah moral terhadap diri sendiri, masalah moral terhadap Tuhan Yang Maha Esa, dan masalah moral terhadap lingkungan sekitar atau sosial. Oleh karena itu, pengajaran moral perlu dijadikan sebagai salah satu tujuan pendidikan untuk mendukung kedua fungsi moralitas tersebut. Teori perkembangan moral Kohlberg dalam Faiz (2013: 7), memandang perbuatan moral bukanlah hasil sosialisasi atau pelajaran yang diperoleh dari kebiasaan dan hal-hal lain yang berhubungan dengan norma kebudayaan. Sebaliknya, kematangan moral seseorang terwujud dalam tingkah laku dan proses penalaran mereka. Nilai moral dianggap sebagai cerminan hati nurani manusia yang didapatkan melalui penghayatan nilai-nilai kehidupan. Pandangan ini mengukur tinggi rendahnya moral individu merupakan hasil dari proses penalaran individu dalam kaitannya untuk pengetahuan dari suatu proses sosial dan nilai kebudayaan.

\section{METODE}

Metode penelitian, pengertian metode berasal dari kata mothodos (Yunani) yang berarti "cara" atau "suatu jalan". Metode merupakan kegiatan ilmiah yang berkaitan dengan suatu cara kerja (sistematis) untuk memahami suatu objek atau subjek penelitian, sebagai upaya untuk menemukan jawaban yang dapat dipertanggung jawabkan secara ilmiah dan termasuk keabsahannya (Ruslan, 2014). Sementara, penelitian adalah bentuk kegiatan ilmiah yang dilakukan secara sistematis melalui proses pengumpulan data, pengolah data, serta menarik kesimpulan berdasarkan data menggunakan metode dan teknik tertentu dengan tujuan menemukan suatu pengetahuan atau kebenaran (Dharma, 2008: 5).

Penelitian ini menggunakan metode deskriptif kualitatif, yaitu metode yang berusaha untuk mengemukakan secara sistematis, baik berupa fakta maupun ciriciri data yang dianggap sebagai ajaran moral dari objek penelitian yang dianalisis, dengan menggunakan pendekatan deskriptif-analitik. Pemilihan metode deskriptif dan pendekatan ini dipilih karena peneliti memandang metode ini sesuai dengan masalah dan metode penelitian yang akan dianalisis.

Sumber data yang digunakan sebagai objek penelitian adalah naskah Melayu berbentuk naskah digital yang berjudul Hikayat Kalilah dan Damina, naskah koleksi Royal Asiatic yang disimpan di SOAS Library. Objek penelitian diperoleh secara langsung melalui tahapan mengunduh dan membaca dengan seksama hikayat ini. Kajian pustaka dalam penelitian ini berasal dari kepustakaan berupa literatur, jurnal, dan teks artikel, serta buku-buku yang memuat informasi, baik yang berkaitan dengan Hikayat Kalilah dan Damina maupun buku-buku lain yang relevan.

Metode pengumpulan data yang digunakan adalah studi pustaka. Metode studi pustaka dilakukan dengan mencari, membaca, mencatat, data pustaka yang diperoleh, baik dari buku-buku, jurnal, literatur, maupun teks-teks sejenis untuk diolah (Zed, 2004: 1-2). Metode ini digunakan karena merupakan metode yang paling mendukung pembahasan permasalahan yang diangkat oleh penulis. Datadata tersebut kemudian dikaji menggunakan teori yang relevan. Penulis sebagai instrumen utama dalam penelitian ini melakukan kegiatan pengumpulkan, 
Tuah Talino

Tahun XIV Volume 14 Nomor 2 Edisi 4 Desember 2020

ISSN 0216-079X E-ISSN 2685-3043

Balai Bahasa Kalimantan Barat

pengidentifikasi, penyeleksi, dan penganalisis data. Penelitian ini dapat dikatakan sebagai human instrument. Artinya, penulis menanggung banyak peran dalam mengumpulkan, menyeleksi, dan menafsirkan data.

Analisis data dalam penelitian ini dilakukan dengan menggunakan metode deskriptif kualitiatif. Dalam metode deskriptif kualitatif, penulis menganalisis dan membuat gambaran berdasarkan data-data dan fakta yang ada. Metode ini akan menyajikan data, pembahasan atau analisisnya serta penarikan simpulan dari topik yang dikaji dalam bentuk uraian atau deskripsi.

\section{PEMBAHASAN}

Hikayat Kalilah dan Damina merupakan naskah Melayu yang tergolong dalam jenis prosa. Hikayat ini berisi kumpulan cerita-cerita binatang yang di dalamnya mengandung hikmah, yang dapat digunakan sebagai cerminan dan media pembelajaran moral manusia. Hikayat Kalilah dan Damina adalah salah satu karya sastra masa lampau yang populer, yang telah ditulis dan disalin ke dalam berbagai versi dan diadaptasi dengan beragam bahasa.

Secara garis besar, hikayat ini bercerita mengenai seorang raja yang mempunyai empat orang putera yang nakal dan susah untuk diberikan nasihat. Melihat hal ini, raja pun khawatir dan kemudian memerintahkan seorang Brahmana yang datang dari negeri Hindi untuk membawakan kitab Hikayat. Berkat kepandaian dan kebijakan Brahmana tersebut, anak-anak raja itupun bisa dididik menjadi manusia yang cerdas, arif, dan bermoral. Hikayat ini, terdapat kisah-kisah berbentuk fabel mengenai cerita-cerita Maharaja Singa beserta kedua sahabat di bawah naungannya yang bernama Kalilah dan Damina sebagai plot utamanya, serta terdapat cerita-cerita binatang lain yang juga berisi banyak hikmah.

Pesan dalam Hikayat Kalilah dan Damina ini dimaksudkan agar para pembacanya menjadi orang yang tinggi pengetahuan ilmunya serta menjadikan arif dan bijak wataknya dari segala ilmu yang didapatnya. Selayaknya dalam sebuah kehidupan, manusia harus berperilaku sesuai dengan tata aturan kehidupan sehingga mampu menemukan nilai kehidupan itu sendiri. Hikayat Kalilah dan Damina ditulis oleh pengarangnya sebagai karya sastra yang berisikan pesan dan nilai moral.

Pada uraian sebelumnya telah dikemukakan bahwa Hikayat Kalilah dan Damina ini banyak berisi cerita yang mengandung hikmah. Hikayat ini secara subtantif bisa dikatakan lepas dari pengaruh kekuasaan kerajaan yang belaku pada masa itu, seperti kebanyakan hikayat yang lain di masyarakat Melayu. Hal ini dapat diindikasikan karena tidak terdapatnya unsur-unsur yang mengagungkan sesuatu, baik tempat maupun tokoh tertentu sebagaimana isi hikayat tersebut.

\section{Pesan Moral Hikayat Kalilah dan Damina}

Cerita dalam hikayat ini dimulai dengan kisah mengenai dua ekor serigala, yang satu bernama Kalilah dan satunya lagi bernama Damina. Pada sebuah negeri bernama Padaliparum. Di sana, terdapat seorang raja yang memiliki empat orang putera yang dungu dan bebal sehingga sulit untuk menerima nasihat. Hal itu yang membuat sang raja menjadi risau, galau, marah, dan juga berduka sekaligus merasa khawatir akan masa depan anak-anaknya tersebut. Dengan karakter yang 
Tuah Talino

Tahun XIV Volume 14 Nomor 2 Edisi 4 Desember 2020

ISSN 0216-079X E-ISSN 2685-3043

Balai Bahasa Kalimantan Barat

seperti itu, tentu saja sang anak akan dapat merusak masa depan silsilah keturunan raja-raja berikutnya. Kemudian, raja memerintahkan seorang Brahmana yang pandai dan bijaksana, yang ahli dalam bercerita untuk mendidik keempat anak raja yang dungu dan bebal tersebut.

Hikayat Kalilah dan Damina bila ditinjau dari aspek nilai moral, dapat dibagi secara garis besar sebagai berikut,: nilai-nilai moral terhadap Tuhan Yang Maha Esa, nilai moral terhadap diri sendiri, serta nilai-nilai moral terhadap sesama makhluk hidup dan lingkungan. Pesan-pesan moral dari hikayat ini bisa ditemukan, baik secara langsung maupun secara tersirat di dalam kisah-kisah yang ada di dalamnya. Pernyataan tersebut menunjukkan bahwa nilai-nilai tersebut telah dimasukkan sebagai bagian orientasi nilai pendidikan. Pada hakikatnya, pendidikan bertujuan untuk mempersiapkan manusia pembelajar sejati yang siap mengarungi sekolah besar kehidupan.

Hikayat Kalilah dan Damina mengajarkan pada manusia agar dapat merenungi setiap episode kehidupannya di dunia. Hasil dari perenungan tersebut, diharapkan akan dapat menjadi dasar bagi pembentukan aspek moralitas manusia yang kemudian terwujud melalui perilaku yang berakhlak dan bermartabat. Perenungan-perenungan tersebut dapat terlihat melalui kutipan sebagai berikut.

"bahwasanya empat perkara yang tiada dapat dipelihara, pertama nasi yang telah berjamur dengan racun, dan keduanya gigi yang bergoyang di tengah, dan·ketiga orang yang khianat, dan keempat menteri yang hendak meIebihi daripada rajanya. Bahwa keempat perkara tersebut itu dapat tiada haruslah dicabutkan dengan akar-akarnya dan dibuang ke dalam laut kalzum.” (Anonim, 1815: 28-29).

Berdasarkan kutipan tersebut diketahui bahwa pesan moral yang hendak ditujukan kepada diri manusia, yaitu agar manusia mampu dan senantiasa berusaha untuk senantiasa menjaga kesehatannya, merenungi aspek kebermanfaatan dari sisa umur yang ada, serta memelihara kepercayaan dalam hubungannya dengan sesama manusia lain. Pesan moral ini jelas berfungsi sebagai cerminan perilaku yang baik untuk dilakukan dan perilaku yang tidak pantas untuk diperbuat oleh manusia yang beradab dan bermartabat. Oleh karena itu, keempat perkara tersebut harus dicabut dan dihilangkan dari dalam diri manusia. Pesan seperti ini ditujukan agar manusia senantiasa mawas diri dalam bertindak selama hidupnya. Sikap mawas diri ini akan melatih manusia untuk dapat bertindak secara proporsional dan profesional sesuai dengan keperluan dan kebutuhannya dalam bertindak (Pratisti \& Prihartanti, 2012: 19). Jadi, manusia harus senantiasa eling dan waspada dalam menjalani setiap episode kehidupannya di dunia, baik itu yang berhubungan dengan sesama manusia, alam semesta, dan Tuhan Yang Maha Esa. Artinya, manusia tidak dapat bertindak semaunya dan seenaknya sendiri karena semua perbuatan akan dipertanggungjawabkan.

Dalam episode yang lain dalam teks Hikayat Kalilah dan Damina dikisahkan tentang sekuen persahabatan. Di suatu tempat, dikisahkan terdapat seorang anak memiliki seekor lembu bernama Satrabah. Pada suatu ketika, lembu tersebut terjatuh dan terjebak di dalam hutan. Lembu tersebut kemudian ditinggalkan oleh tuannya karena merasa lembu itu sudah tidak dapat diselamatkan lagi. Singkat cerita, lembu yang bernama Satrabah itu selamat dan 
Tuah Talino

Tahun XIV Volume 14 Nomor 2 Edisi 4 Desember 2020

ISSN 0216-079X E-ISSN 2685-3043

Balai Bahasa Kalimantan Barat

kemudian bertemu dengan raja singa. Satrabah lalu mendapat kepercayaan dari raja singa, dan bahkan keduanya menjalin tali persahabatan. Cerita ini kemudian dilanjutkan dengan kisah dua ekor serigala bernama Kalilah dan Damina yang awalnya bijaksana, tetapi kemudian menjadi jahat karena rasa iri dan dengki dalam hatinya melihat lembu tersebut justru yang terpilih menjadi kepercayaan raja singa. Kemudian, keduanya, Kalilah dan Damina menghasut raja singa agar menjebak lembu Satrabah hingga Satrabah dibunuh oleh raja singa tersebut.

Cerita ini memiliki pesan moral mengenai nilai-nilai kesetiaan dan pesan bahwa hendaknya manusia harus senantiasa memelihara hubungan dengan orang lain. Cerita ini juga ingin menyampaikan bahwa hendaknya manusia tidak memelihara sifat iri dan dengki di dalam hati masing-masing. Sifat iri dan dengki dapat menjadi racun kehidupan yang sangat mematikan, terlebih lagi bila melihat pencapaian orang lain. Pesan tersebut terlihat jelas terdapat pada kutipan di bawah ini.

\footnotetext{
"...barang siapa yang berbuat empat perkara ini maka sekali-kali tiadalah ia mencium bahu surga, pertama orang yang mengampungkan harta haram, keduanya orang yang merusakkan hubungan kekeluargaan, dan ketiganya orang yang merusakkan anak · istri orang, dan keempatnya orang yang menceraiberaikan orang dengan sahabatnya dengan tiada sebenamya." (Anonim, 1815: 44).
}

Pada cerita yang lain, dikisahkan pada suatu tempat terdapat seekor kijang yang terkena jaring pemburu. Kemudian, melintas seekor burung gagak dan melihat kejadian tersebut. Burung gagak yang melihat hal tersebut menyampaikan kejadian tersebut kepada sahabatnya, tikus dan kura-kura. Singkat cerita, kijang itu akhirnya dapat melepaskan diri dengan selamat dari jaring pemburu karena berkat pertolongan dari burung gagak, tikus, dan kura-kura tadi.

Akan tetapi, ketika mereka hendak meloloskan diri, kura-kura yang terlalu lambat jalannya, jauh tertinggal di belakang dan akhirnya dapat ditangkap oleh pemburu. Untuk menyelamatkan temannya, burung gagak ini pun menyuruh supaya kijang itu berpura-pura mati. Kijang itu lalu berpura-pura tergeletak di tengah jalan bersama dengan burung gagak yang ikut bertengger di atasnya layaknya sedang memakan bangkai kijang tersebut. Ketika pemburu melihat hal tersebut di depan matanya, lalu dilemparkannya kantong kecil berisi kura-kura yang ditangkapnya tadi. Kesempatan tersebut lalu digunakan sebaik-baiknya oleh tikus dan digigitnya tali kantong kecil itu demi menyelamatkan kura-kura itu. Setelah melihat kura-kura berhasil diselamatkan, maka kijang itupun segera melompat lari dan burung gagak pun juga segera terbang. Akhirnya, selamatlah mereka semua dari kekejaman sang pemburu.

Pesan moral yang hendak disampaikan dalam cerita itu, antara lain adalah tentang kecerdikan, kesetiakawanan, dan kerjasama dalam menghadapi suatu masalah. Pendidikan seperti ini sangat penting terutama dalam menghadapi berbagai masalah kehidupan dunia modern yang semakin kompleks. Namun, yang terjadi saat ini, justru budaya individualisme yang berlebihan telah melunturkan semangat untuk bekerja sama. Setiap orang terjebak dalam prasangka negatif sehingga mereka sulit untuk dapat bekerja sama. Padahal, yang dibutuhkan dalam era digital dan era sosial saat ini adalah super tim, bukan superman. Artinya, 
dengan bekerja sama, semua permasalahan yang ada insya Allah dapat diselesaikan dengan baik.

Di dalam teks Hikayat Kalilah dan Damina juga disampaikan tentang nilainilai kesetiakawanan. Hal itu terlihat secara jelas melalui kutipan sebagai berikut.

"Hai anakku keempatnya, demikianlah halnya orang yang bersahabat serta dengan kelakuan setiakawan seorang dengan seseorang niscaya selamatlah adanya" (Anonim, 1815: 65).

Berdasarkan kutipan tersebut dapat diketahui bahwa nilai-nilai kesetiakawanan atau solidaritas merupakan hal yang penting dalam membangun sebuah persatuan dalam kehidupan yang penuh perbedaan. Sebab sikap setia kawan atau solidaritas akan membentuk kepercayaan dan menghasilkan kerukunan. Hikayat Kalilah dan Damina sebagai sebuah cerminan pembelajaran moral ingin menyampaikan pesan yang positif untuk membangun solidaritas pada setiap pembacanya. Pesan-pesan moral tersebut disampaikan, baik secara tersurat maupun tersirat melalui berbagai tokoh, cerita, peristiwa, sekuen, dan episode dalam Hikayat Kalilah dan Damina. Oleh karena itu, diperlukan kepekaan pembaca dalam menangkap semua fenomena-fenomena literer yang terdapat dalam teks Hikayat Kalilah dan Damina. Selain itu, juga diperlukan kecerdasan dalam merelanvansikan atau mengaitkan antara fenomena yang ada dalam teks dan fenomena yang ada dalam kehidupan nyata (Wirajaya, 2007). Dengan demikian, pembelajaran aspek moral dapat lebih mengena dan merasuk dalam sanubari pembaca dan generasi yang akan datang. Harapannya, mereka akan tumbuh menjadi generasi-generasi yang cerdas, beradab, bermartabat, dan siap terjun dalam sekolah besar kehidupan.

\section{Hikayat Kalilah dan Damina sebagai sarana Pembelajaran Moral}

Masalah tentang moral merupakan permasalahan yang memiliki ruang lingkup yang kompleks dan luas. Solusi dari permasalahan moral secara tepat adalah melalui pendidikan yang senantiasa berusaha untuk menyeimbangkan kecerdasaan antara intelegensi, emosional, dan spiritual. Dalam hal ini, pembelajaran moral sebagai salah satu bagian dalam model pendidikan. Dalam hikayat ini, dituliskan sebuah pesan bagi para pembacanya agar selalu memiliki pedoman kehidupan. Pesan tersebut terdapat dalam kutipan syair yang tertera pada bagian akhir teks sebagai berikut.

\author{
Barang siapa membaca hikayat ini \\ jangan lengah hatinya kesana-kesini \\ Hendaklah ingatkan pesan ini \\ supayaku hasil artinya ini/
}

Jikalau ingat sekali ceritanya jadi hasil atas dirinya
(Anonim, 1815: 89)

Berdasarkan kutipan tersebut dapat diketahui bahwa pesan yang terkandung dalam hikayat itu memang ditujukan sebagai sebuah pedoman dan pengajaran moral untuk para pembacanya. Pengarang menyampaikan pesan bagi 
Tuah Talino

Tahun XIV Volume 14 Nomor 2 Edisi 4 Desember 2020

ISSN 0216-079X E-ISSN 2685-3043

Balai Bahasa Kalimantan Barat

setiap pembaca hikayat itu "supaya tidak lengah hatinya kesana-kesini". Pada ungkapan "tidak lengah hatinya..." memiliki makna bahwa manusia harus memiliki kekuatan moral sebagai suatu pedoman kehidupan. Kekuatan moral ini akan membuat manusia senantiasa bertindak sesuai dengan aturan-aturan yang ada dan lebih menghargai sesamanya. Pengarang juga secara terus-menerus memberikan tanda agar hikayat itu tidak hanya sebagai bacaan penglipur lara atau menghibur semata, tetapi juga mengandung atau memuat nilai-nilai ajaran moral yang bisa bermanfaat bagi para pembacanya.

Hikayat Kalilah dan Damina adalah salah satu bentuk karya sastra yang mengandung cerminan konsep dari ketiga faktor pengajaran moral tersebut. Secara tersurat dan tersirat banyak ditemukan pesan-pesan yang secara jelas menunjukkan bagian dari proses pengajaran moral, baik ajaran moral dari segi inteligensi, emosional maupun spiritual. Hal itu terlihat melalui kutipan berikut.

\author{
Banyak dalilnya tipu dan daya \\ janganku budi teperdaya \\ Sesat di majelis jadi kecewa \\ daripada budi menjadi hilang jiwa/ (Anonim, 1815: 91) \\ Akal yang banyak bagiku tentu \\ Supaya jadi perangai yang patut
}

Kutipan di atas memiliki maksud bahwa, kehidupan dunia ini banyak perihal yang bisa menjadi tipu daya, maka manusia harus senantiasa eling dan waspada serta memiliki pemahaman dan pengamalan budi pekerti yang baik, sekaligus juga disertai dengan kecerdasan akal yang mumpuni pula agar mereka mampu berpikir dan bertindak dengan tepat. Tentu saja, hal tersebut dapat menjadi contoh suri teladan bagi manusia yang lain agar mereka dapat tumbuh dan berkembang sebagai manusia-mausia yang ideal atau insan kamil (Braginsky, 1998), (Haryadi, 2013), (Wirajaya, 2019). Dalam proses pendidikan yang semacam inilah ada integrasi antara kecerdasan inteligensi dan kecerdasan spiritual. Hal itu terlihat melalui kutipan berikut.

"Bermula barang siapa tiada menolak pengajar orang yang budiman namanya ia akhirnya akan menyesal jua, umpama orang sakit tiada menoleh kata orang yang mengobati, barang kehendak demikian namanya ia penyakit itu mungkin akan bertambah-tambah jua" (Anonim, 1815: 40)

Kutipan tersebut berisi pesan mengenai pentingnya menerima sebuah pengajaran dari orang yang lebih tahu atau mumpuni, termasuk di dalamnya mampu menerima segala nasihat yang diberikan kepada manusia. Sebab apabila manusia tidak menghiraukan nasihat-nasihat yang telah diberikan, maka pasti akan timbul rasa penyesalan di kemudian harinya.

Dari segi kecerdasan emosional, moral mengatur bahwa manusia harus mampu mengendalikan hubungannya, baik dengan diri sendiri, maupun dengan orang lain. Misalnya, etika dalam mengemukakan sebuah penilaian kepada orang lain, dan sikap dalam bertutur kata, yakni hendaknya selalu berlaku lemah lembut saat berbicara dan memperhatikan aspek-aspek lainnya ketika ada yang 
Tuah Talino

Tahun XIV Volume 14 Nomor 2 Edisi 4 Desember 2020

ISSN 0216-079X E-ISSN 2685-3043

Balai Bahasa Kalimantan Barat

berbicara. Dalam teks Hikayat Kalilah dan Damina, pesan tersebut dituliskan seperti berikut.

"Maka kata Damina, adapun pelajari aku dengan kataku dengan lemah lembut..." (Anonim, 1815.: 34).

Berdasarkan kutipan tersebut diketahui bahwa berlemah lembut dalam berbicara dan bertingkah laku terhadap orang lain adalah bentuk-bentuk perilaku yang ditujukan untuk menghormati keberadaan orang lain. Dengan sikap hormat kepada orang lain, maka akan memudahkan manusia untuk membuat hubungan yang dekat dari orang lain, seperti bekerja sama dan mencapai tujuan-tujuan bersama. Ajaran yang serupa seperti ini juga terdapat di dalam agama Islam. Salah satunya terdapat pada penggalan ayat di bawah berikut.

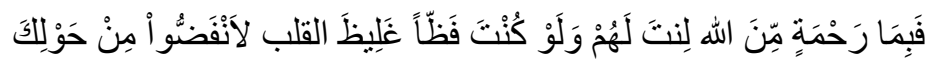
Fabimā rahmatin minallahi linta lahum walau kunta fazh-zhan ghalizzhal qalbi länfadhdhü min haulika

"Maka disebabkan rahmat dari Allah-lah, kamu berlaku lemah lembut terhadap mereka. Sekiranya kamu bersikap keras lagi berhati kasar, tentulah mereka menjauhkan diri dari sekelilingmu..." (QS. Ali Imron: 159).

Jadi, secara spiritual, Hikayat Kalilah dan Damina juga telah memberikan pesan-pesan pemaknaan dalam kehidupan keseharian manusia, seperti mawas diri, dan bersikap rendah hati, serta selalu mengedepankan nilainilai kebenaran. Selain itu, Hikayat kalilah dan Damina juga telah memberikan pemahaman bahwa setiap manusia memiliki kedudukannya masing-masing, kedudukan tersebut bukanlah karena harta dan sosialnya, melainkan karena cerminan moral dari akhlaknya. Sebab semua perkara harta dan sosial pada saatnya akan jatuh, sedangkan apabila manusia berpegang pada akhlak, maka ia akan selamat sampai akhir.

\section{PENUTUP}

Inti ajaran moral yang ingin disampaikan dan dicapai dari Hikayat Kalilah dan Damina ini adalah gambaran manusia ideal, yakni manusia yang paham dan bertindak dalam nilai-nilai moral, yaitu manusia berakhlak. Manusia berakhlak akan selalu mengedepankan perbuatan-perbuatan mulia dalam setiap laku kehidupannya. Perbuatan mulia selain juga dianjurkan di dalam agama, juga merupakan naluri dari hati nurani dari setiap manusia yang berakal. Pemikiran seperti inilah yang mendasari dituliskannya Hikayat Kalilah dan Damina oleh pengarangnya sehingga kehadiran hikayat tersebut diharapkan mampu membantu manusia untuk lebih memahami nilai-nilai kehidupan yang nyata.

Hikayat Kalilah dan Damina dituliskan dalam bentuk cerita-cerita yang mengandung hikmah dan pesan moral di dalamnya. Tradisi bercerita adalah sebuah ciri khas bentuk pembelajaran di dalam masyarakat, khususnya dalam masyarakat Melayu. Dengan bahasa yang mudah dipahami oleh masyarakatnya 
Tuah Talino

Tahun XIV Volume 14 Nomor 2 Edisi 4 Desember 2020

ISSN 0216-079X E-ISSN 2685-3043

Balai Bahasa Kalimantan Barat

pada saat itu, Hikayat Kalilah dan Damina hadir sebagai sebuah karya sastra yang baru dan berbeda dari kebanyakan hikayat yang telah ada lebih dulu dalam masyarakat, yakni sebagai bentuk cerminan moral masyarakat.

Nilai-nilai moral yang terdapat dalam Hikayat Kalilah dan Damina masih relevan dengan tujuan dan cita-cita pendidikan Indonesia saat ini, yakni pendidikan karakter. Pendidikan karakter ini lebih berorientasi pada pembentukan mental, sikap, dan perilaku manusia. Dengan berbekal karakter dasar inilah diharapkan mampu sebagai penyempurnaan dalam mengarahkan manusia menuju pada arah kehidupan yang lebih baik. Oleh karena itu, Hikayat Kalilah dan Damina masih layak untuk terus diangkat dan disajikan sebagai bahan pembelajaran dalam konteks dunia pendidikan, baik secara khusus maupun contoh pengajaran moral dalam masyarakat secara umum.

Selain itu, cerita-cerita yang terdapat dalam teks Hikayat Kalilah dan Damina bisa digunakan sebagai sebuah alternatif media pembelajaran moral yang cocok diterapkan untuk anak-anak dalam bentuk dongeng. Sebab, cerita di dalamnya yang sebagian besar berkisah tentang tokoh-tokoh binatang (fabel). Cerita fabel merupakan salah satu jenis cerita yang digemari oleh anak-anak. Hal ini terbukti bahwa Hikayat Kalilah dan Damina masih sangat representatif dalam kehidupan bermasyarakat hingga masa sekarang ialah banyaknya versi buku fabel maupun novel yang terilhami dari Hikayat Kalilah dan Damina, termasuk di dalamnya yang menggunakan judul Hikayat Kalilah dan Damina, dan atau Hikayat Kalilah dan Dimnah.

\section{DAFTAR PUSTAKA}

Anonim. (1815). Hikayat Kalilah dan Damina, Singapore: Royal Asiatic Society.

Baidaba. (2002). Hikayat Kalilah Wa Dimnah. (D. Ismail, Ed.). Jakarta: Balai Pustaka.

Baried, dkk. (1979). Memahami Hikayat Dalam Sastra Indonesia. Jakarta: Pusat Pembinaan dan Pengembangan Bahasa.

Braginsky, V. I. (1998). Yang Indah, Berfaedah dan Kamal:sejarah Sastra Melayu dalam abad 7-9. Jakarta: INIS.

Chilmiy, A. (2014). Dilema Moral Remaja Masjid Yang Bekerja Sebagai Penjaga Cafe Remang-remang di Embong Malang Surabaya. Surabaya: UIN Sunan Ampel.

Dharma, S. (2008). Pendekatan, Jenis, dan Metode Penelitian. Jakarta: Departemen Pendidikan Nasional.

Faiz, A. (2013). Perkembangan Moral: Teori Piaget \& Kohlberg. In Academia (Vol. 2, hal. 1-17).

Haryadi, H. (2013). SUFISME DALAM SYAIR HAMZAH FANSURI. LITERA, 11(2). https://doi.org/10.21831/ltr.v11i2.1066

Hasanah, Enung (2019). Perkembangan Moral Siswa Sekolah Dasar Berdasarkan Teori Kohlberg. JIPSINDO. Volume 6, Nomor 2 (131-145)

Kamus Besar Bahasa Indonesia. (2008). Jakarta: Pusat Bahasa Departemen Pendidikan Nasional

Pratisti, D. W., \& Prihartanti, N. (2012). Konsep Mawas Diri Suryomentaram dengan Regulasi Emosi. Jurnal Penelitian Humaniora, 13(1), 16-29. 
Tuah Talino

Tahun XIV Volume 14 Nomor 2 Edisi 4 Desember 2020

ISSN 0216-079X E-ISSN 2685-3043

Balai Bahasa Kalimantan Barat

Ruslan, R. (2014). Metode Penelitian Public Relations dan Komunikasi. Jakarta: PT. Raja Grafindo Persada.

Wirajaya, A. Y. (2007). Hakikat Sastra. Surakarta.

Wirajaya, A. Y. (2014). Mitos dalam Perspektif Sastra Bandingan. Surakarta: Assalam Publishing.

Wirajaya, A. Y. (2015). Tekstologi: Sebuah Pengantar. Surakarta: Awan Pustaka.

Wirajaya, A. Y. (2019). Estetika Puitik Kesusastraan Melayu Klasik. Surakarta: Oase Pustaka.

Zed, M. (2004). Metode Penelitian Kepustakaan. Yayasan Obor Indonesia.

Zuriah, N. (2007). Pendidikan Moral dan Budi Pekerti dalam Perpektif Perubahan. Jakarta: Bumi Aksara. 